\title{
Usjek u hrvatskom antologijskom haikuu
}

\section{Abstract: Kire in Anthological Croatian Haiku Poetry}

The article deals with the Japanese poetic and conceptual terms kire and kireji, situating them within Croatian literary theory and practice. It consists of three parts: the first is titled "Signifier" and it focuses on the delimitation of both key terms and their reception in Croatia. Based on the analysis of the current situation, a suggestion to use „usjek” and „usječnica” as translations is made, while elaborating on the link of both terms with caesura as a close literary phenomenon. The second part ("Signified") discusses the specifics of the kire with examples selected from Japanese literature. Special attention is paid to contemporary cognitive-literary theories and the characteristics which kire shares with metaphor and blending. The final part ("Corpus Analysis") uses examples selected from three anthologies of Croatian haiku poetry to demonstrate some possibilities of distant reading (searching for kire, vector word models) in order to completely define and rehearse kire within domestic literary theory.

Keywords: haiku, kire, kireji, blending, distant reading

\section{Označitelj}

Kako je razaznatljivo iz naslova ovoga rada, primarni cilj stranica koje slijede bit će predstavljanje i analiza termina „usjek” u haiku-pjesmama, s posebnim naglaskom na hrvatske antologije. Metodologija će kombinirati književno-znanstvene spoznaje s analitičkim pristupom „udaljenoga čitanja" (usp. Moretti), koji će se primijeniti na korpus hrvatske antologijske haiku-poezije. Time će se ujedno ostvariti i sekundarni cilj rada, a to je demonstracija primjenjivosti na haiku-poeziju nekih metoda „digitalne humanistike” (usp. Nikolić za eksplikaciju i implikacije toga termina za domaće književno polje te Da 2019 za utemeljenu kritiku dosadašnjih postignuća). Za početak je potrebno napomenuti da, unatoč visokoj učestalosti kojom se pojavljuje u hrvatskom haikuu, usjek nema 
jasno definirane granice u odnosu na srodne termine, kao ni ustaljen prijevod na hrvatski jezik. Umjesto prijevoda u stručnoj i pratećoj literaturi obično se koristi engleska transkripcija riječi kireji ([kiređi]), koja se na japanskom piše 切れ字 ili 切字, a koja je ustvari zaseban termin za koji se ovdje predlaže prijevod „usječnica”.

Vladimir Devidé, pionir hrvatske japanologije koji je uvelike zaslužan za to što se haiku vrlo uspješno proširio u hrvatskoj književnosti, o kireji piše ovako: „Spomenimo, bar ukratko, i ovu osobitost japanskog jezika: Postoje riječi, tzv. kireji, koje ne odgovaraju nekom pojmu već im je uloga bliža dijakritičkim znakovima; one su neke vrste oznaka tonaliteta koji se pridružuje rečenom, neke vrste 'usklika' koji iskazuju ili usmjeruju ili posebno podcrtavaju boju osjećaja ili raspoloženja pjesnika pri opisanom događaju (Japanska 84)." U nastavku Devidé lapidarno navodi i opisuje osam primjera (ya, kana, keri, yara, yo, zo, ka i to), upućujući na činjenicu da ovaj izbor nije konačan i da se radi o najčešćim riječima koje se međusobno razlikuju značenjem i funkcijom, sukladno navodnim pjesničkim afektivnim stanjima. Svoj odlomak o temi kireji on završava sljedećom rečenicom: „Svi su ti kireji postpozicije, i kod čitanja redovno iza njih dolazi pauza - kireji su 'riječi što sijeku' ...." (Japanska 84) Kraj odlomka ujedno je i kraj pozornosti koju je Devidé odvojio za kireji u svojoj knjizi od tristotinjak stranica koja predstavlja referentnu točku za hrvatski haiku, pa se može reći da se radi o lakuni koju nije naodmet popuniti.

Devidé je dosljedan u rabljenju terminologije i koristi se isključivo japanskim riječima, ne predlažući prijevodne inačice za termine poput kireji, kigo (prijedlog za hrvatski prijevod: dobnica) ili sam haiku, koji tretira kao indeklinabilnu riječ muškog roda (Japanska 8, 65; dotična praksa neće se slijediti u ovome radu budući da se riječ u međuvremenu još više udomaćila te se u praksi slobodno deklinira). No, iako haiku nema potrebe prevoditi, osim možda da bi se naglasila uvriježenost jednoga pjesničkog oblika u drugoj književnosti (kao što „zvonjelica” čini za „sonet”), govoreći o kireji ipak je potrebno uvesti distinkciju kako bi se izbjegla terminološka zabuna. Naime, „riječi koje sijeku” (kireji, 切れ字) formalna su manifestacija usjeka (kire, 切れ), koji pak u svakome haikuu može postojati neovisno od riječi ili znaka kojim se izražava. Pojava usjeka toliko je važna da se uzima kao jedna od tri pravilnosti koje određuju japanski klasični haiku, iako je Devidé ne navodi kao važan element (Japanska 76). Druga je pravilnost struktura stiha koji se sastoji od tri dijela (prijedlog za hrvatski prijevod: trodjelnica haikua) od 5, 7 i 5 mora, odnosno ukupno 17 mora, 
što je otprilike ekvivalentno broju samoglasnika u stihu, s tom razlikom da u japanskom pjesništvu slog može sadržavati jednu ili dvije more, dakle može biti metrički kratak ili dug (Petrović 285). Treća je pravilnost prisutnost dobnice (kigo), a iako nijedan od ta tri elementa nije neophodan, usjek se u dugoj povijesti haikua uz izmjene i prilagodbe pojavljuje kao pravilo žanra i stoga zavređuje pozornost.

Nadalje, iako je Devidé načelno u pravu kada ji (字) prijevodi s „riječi”, on griješi kada ih uspoređuje s „dijakritičkim znakovima”, budući da ti znakovi modificiraju samo slovo kojem su pridruženi, a ne čitave riječi ili kompleksnije jezične strukture. Ipak, sasvim je prihvatljiva usporedba s interpunkcijskim znakovima, pa je vjerojatno da se na ovom mjestu Devidé jednostavno zabunio i umjesto „interpunkcijskim” napisao „dijakritičkim”, pogotovo stoga što ji doslovno podrazumijeva bilo kakav znak, bez obzira na jezičnu upotrebu. To znači ne samo da im je „uloga bliža [interpunkcijskim] znakovima", nego i da kireji doslovno mogu biti i izvan Japana uglavnom i jesu interpunkcijski znakovi koji označavaju usjek, koji se otprilike od druge polovice 20. stoljeća počeo označavati i praznim prostorom između riječi i/ili redaka haikua. Te je znakove stoga potrebno razlikovati i drukčije imenovati, za što je ovdje već predložen termin „usječnice” kao izvedenica od „usjeka”.

Uvođenjem ovakve distinkcije kako bi se razjasnila dva različita, ali blisko povezana termina, istodobno se stvara poveznica između japanskoga termina „kire” i izvorno latinskoga termina „cezura”, kojoj je „usjek” ustvari prijevod u domaćoj versifikaciji. Ipak, kako bi se izbjegla moguća zabuna, odmah treba istaknuti sljedeće: „kire” i „kireji” koji ga eventualno može označavati u japanskom pjesništvu (ne samo u haikuu) imaju načelno sličnu funkciju kao i „cezura” i njoj eventualno pripadajući interpunkcijski znakovi u europskom pjesništvu, no glavna je razlika u tome što „kire” primarno predstavlja semantički usjek, dok „cezura” označava sintaktički usjek ili odmor u stihu. Upravo zbog te velike načelne razlike podesnije je odabrati hrvatsku nego latinsku inačicu riječi, kako bi se istaknula neuvjetovanost izvornim shvaćanjem cezure. Odabirom „usjeka” kao najbližeg prijevodnog ekvivalenta za „kire” prema tome preuzimamo i modificiramo neke postojeće karakteristike cezure koju Svetozar Petrović definira ovako:

Za stihove silabičke i silabičko-tonske versifikacije, osobito za duže stihove, karakteristična je i cezura. I taj je termin posuđen iz klasičke metrike; tamo on znači odmor u stihu, koji presijeca 
stopu (naš je termin za to usjek), i razlikuje se od dijereze (rastave), odmora koji se poklapa s krajem stope. ... Cezura (presjek ili zasjek) jest stalna granica među riječima iza nekog sloga, provedena kroza sve stihove neke pjesme. ... Cezura se često naziva i odmorom, ali taj naziv zavodi na pogrešnu misao da se na mjestu cezure [treba nakratko zaustaviti u čitanju naglas].

(Petrović 287)

Druga najvažnija razlika između cezure i usjeka (u smislu kire) nalazi se u stalnosti cezure koju Petrović spominje kao nužnost versifikacije u kojoj se cezura pojavljuje, a koja načelno izostaje u haiku-pjesmama jer se u njima usjek može pojaviti na bilo kojem mjestu. $\mathrm{K}$ tome, u jednom haikuu može biti i više kire odnosno kireji, kao što i u stihovima europskih jezika može biti više cezura, primjerice čak tri po jednom retku ternarno fraziranoga dvostruko rimovanog dvanaesterca. Nadalje, dok je cezura u nekim stihovima obavezna, kire(ji) se u pjesmi ne mora ni pojaviti, kao ni metar 5-7-5 ili dobnica (kigo), iako su takve pjesme u Japanu relativno rijetke prije 20. stoljeća. No, u praksi se i cezura u europskim stihovima može premještati za nekoliko slogova prije ili poslije uobičajenog položaja u narodnoj ili umjetničkoj lirici.

S obzirom na pomičnost cezure, nema također ni većih zapreka da kire prevedemo usjekom, pogotovo ako imamo na umu da se usječnice (kireji) u najvećem broju slučajeva ustvari pojavljuju na 5., 12. ili posljednjem, 17. slogu (odnosno mori). Pojava kire na kraju stiha dobro ilustrira da taj termin kao ni cezura ne pretpostavlja pauzu prilikom čitanja jer do stanke ionako mora doći na samome kraju stiha i pjesme. U klasičnome japanskom haikuu, onome nastalom u razdoblju Edo ili Tokugawa (1603. - 1868.), usječnica se nerijetko pojavljuje na kraju kako bi naglasila posljednju cjelinu od pet slogova (mora), koja time retroaktivno postaje zasebni članak, odnosno cjelina izdvojena usjekom. Cezura nikada ne funkcionira na taj način, što je razlog više da je ne izjednačavamo u potpunosti s kire, već da se poslužimo „usjekom” i „usječnicama” kao terminima koji kombiniraju neke od najvažnijih karakteristika različitih, ali ipak usporedivih stihotvornih fenomena.

Praksa potpunog ili djelomičnog izjednačavanja cezure i kire inače nije neuobičajena, pa se njome poveo i Makoto Ueda, jedan od suvremenih autoriteta na polju japanske književnosti i haikua (vidi Ueda 1983). Ukoliko je poistovjećivanje (elemenata) cezure i kire odnosno kireji prisutno u komparativnim proučavanjima haikua, možemo se zapitati zašto se ono nije pojavilo i u našoj 
literaturi? Načelni se odgovor može svesti na činjenicu da se haiku u domaćoj literaturi uglavnom definira kao pjesma sastavljena od tri stiha, pa tako i kod dvojice ovdje citiranih domaćih autora: za Devidéa haiku je pjesma „prikaz jednog doživljaja sažet u sedamnaest slogova ... [u] tri stiha s po 5, 7 i 5 slogova” (Japanska 69), a Petrović je slično definira kao „tercet sa svega 17 slogova (5, 7, 5)" (319). Petrović u svojem radu haiku spominje samo u dotičnoj fusnoti, dok se Devidé dosljedno na njega referira kao na pjesmu u tri stiha ili tristih (kod Petrovića: „trostih”). Ako prihvatimo takvu definiciju haikua, onda bi se cezura u principu trebala pojaviti tri puta, po jednom u svakome retku, i k tome bi svaki put trebala bila na istome mjestu, recimo nakon trećeg sloga u svakome od redaka (otprilike na polovici), što nimalo ne odgovara tradicionalnom obliku haikua.

Međutim, haiku bi se ustvari trebao definirati kao lirska pjesma napisana u jednom stihu, čime onda postaje prihvatljivo u njega uvesti cezuru jednom, dvaput ili nijednom, kao što se i događa u praktički svim postojećim haiku-pjesmama, a ne tri puta kao što bi se načelno trebalo učiniti kada se haiku definira kao tercet. Dapače, u povijesti razvoja haikua kire(ji) se i koristio upravo da bi dodatno označio hokku odnosno prvi stih renge, dulje „ulančane pjesme” koja se sastojala od različitog broja stihova određenih naizmjeničnom izmjenom 17 i 14 slogova (mora) te niza drugih pravila - koji su im određivali jezični sastav. I u tom smislu kire odudara od cezure jer se ona uspostavlja ponavljanjem unutar različitih redaka jedne pjesme, no za haiku kire, odnosno usjek, upravo time uspostavlja jedinstvo između različitih haiku-pjesama/stihova. Naime, iako se ne nalaze u istoj pjesmi, stihovi haikua upućuju na zajednički književni oblik pomoću onoga što je Haruo Shirane nazvao „vertikalnom osi” haiku-poezije (ili općenitije haikai), a odnosi se na specifičnu intertekstualnost koja svaki haiku „povezuje s povijesti i drugim književnim tekstovima” i time u povijesnoj perspektivi čini podudaranje s cezurom vidljivom i razumljivom (Shirane "Beyond").

Shirane nam može pomoći u definiranju hokkua preko kire i kireji, pogotovo stoga što se on pri tome poziva na najutjecajniji autoritet haikua uopće:

Riječ koja siječe (kireji), nužni dio hokkua, često je za svaki hokku stvarala dinamiku dva povezana stiha unutar ograničenja hokkua na sedamnaest slogova. Kao što je Bashō primijetio u Sanzōshiju:

'Stih bez riječi koja siječe [usječnice] nema formu hokkua ili početnoga stiha. Umjesto toga, on zadobiva formu nadodanoga stiha. Čak i ako se riječ koja siječe [usječnica] pridoda u hokku, on još 
uvijek može zadobiti formu dodanoga stiha. Ti stihovi nemaju pravi rez [usjek]. ... U klasičnoj rengi razvila se tradicija od osamnaest riječi koje sijeku [usječnica] koje su postale standardne za haikai" (Traces 100; slijedi nabrajanje svih 18 usječnica).

Uzimajući u obzir sve navedeno, jasno je da klasično shvaćanje haikua i hokkua iz kojega je nastao nužno podrazumijeva prisutnost kire odnosno kireji.

Dakle, iako nije upitno da se u slučaju haikua radi o lirskoj formi koja sadrži određen oblik semantičke stanke te se povijesno i konceptualno ulančava u veće oblike razlikujući se od proze, legitimno je pitanje kako će se ta forma manifestirati konkretno u svakom zapisivanju stiha. Manifestacija koja se tijekom 20. stoljeća uobičajila prvo u Europi, a kasnije i drugdje izvan Japana, haiku zapisuje u tri stihovna retka, što ipak ne znači da se radi o tri različita stiha. Međutim, upravo s obzirom na usjek takvo „troredno" zapisivanje nije jedina prihvatljiva varijanta, o čemu nam opet može posvjedočiti Ueda kad navodi primjer pjesnika Seisensuija: „Veliko poštovanje prema cezuri Seisensuija je navelo da inzistira kako je haiku strukturno pjesma od dva retka. Iz tog razloga prilikom [transliteracije] klasičnih haikua svaku je pjesmu ispisao u dva retka; isto tako, kad god je prevodio haiku na engleski prepjevao ga je u nerimovanom distihu." (321) Ueda spominje i kako se Seisensui oštro usprotivio odluci jednog projekta za promicanje japanske poezije u inozemstvu iz 1950-ih godina da se haikui prevode beziznimno u tri retka, iako se on zalagao da prijevodi budu u dva retka čija će se granica obilježiti pojavom cezure odnosno kire(ji). Njegov je glavni prigovor bio da specijalisti za englesku književnost koji su donijeli tu odluku, koja je doprinijela današnjem de facto globalnom standardu ispisivanja haikua u tri retka, nisu imali osjećaja za ritam haikua i nužnost da se on odredi ne samo rasporedom mora, nego i prisutnošću usjeka.

Sa sličnim se poteškoćama susreće svaki proučavatelj haikua, pogotovo kada ih obrađuje na više jezika, i stoga je uputno navesti barem još jedan primjer koji pokazuje kako se osnovni umjetnički postupci i njima pripadni termini mogu različito shvatiti i protumačiti u (prijevodnom) kontekstu druge književnosti. U sličnoj situaciji kao i Seisensui i njegovi suradnici nedavno se našao David Landis Barnhill, urednik i prevoditelj zbirke Bashōovih izabranih pjesama. On je zamijetio kako izmjena slogova od 5, 7 i 5 mora u japanskom uspostavlja specifičnu kadencu, koja ustvari postoji u svakom razvijenom lirskom sustavu, pa na temelju toga iznosi sljedeće: 
više voli[m] govoriti o strukturi [stiha] kao o ritmu pet-sedam-pet. ... Taj obrazac je svakako prisutan u japanskom. Iz tog se razloga ne slažem s metodom prevođenja japanskog haikua u jednom retku. To su trodijelne pjesme, i iako su otisnute u jednome retku [na japanskom], japanski

čitatelj posjeduje svijest o tom ritmu koju čitatelj jednoga retka na engleskom ne može imati. S druge strane, slažem se da konvencionalna tehnika upotrebe tri odvojena retka u prijevodu također zavodi na stranputicu: izvornik je tečniji, čak i kada ima usječnicu." (6)

Za razliku od Seisensuija, koji ustvari inzistira na grafičkoj podjeli svakoga haikua s usjekom na članke („dijelovi stiha koje [cezura] rastavlja”; Petrović 287), Barnhill unutarnju strukturu stiha haikua određuje isključivo ritmički. To je također legitiman izbor koji neizravno ide u prilog tumačenju kire kao književnog postupka bliskog cezuri jer oboje svojim položajem doprinose određivanju ritma u stihu. Pritom rješenje koje Barnhill primjenjuje za pisanje i prijevod haikua posljednjih godina postaje sve uobičajenije, a sastoji se od prepjeva ispisanog u tri retka i transliteracije u jednom retku. U stručnoj literaturi obično se navodi i japanski izvornik uz doslovan prijevod. Za potrebu ilustracije svega što je do sada navedeno, evo stoga pet Bashōovih pjesama iz Barnhillova izbora (stranice 130, 19, 24, 72, 102) u sve četiri varijante: japanski izvornik, transliteracija (u kurzivu), doslovni prijevod i metrički odgovarajući prepjev na hrvatski (u tri retka), uz podvučene usječnice:

\section{1. 雪を待つ上戸の顔や稲光}

yuki o matsu / jōgo no kao ya / inabikari

[snijeg čekati / pilci od lica / bljesak munje]

dok čekaju snijeg

izraz lica pilaca -

zabljesne munja

2. 京は九万九千くんじゅの花見かな

kyō wa / kuman-kusen kunju no / hanami kana

[prijestolnica je / devedeset devet tisuća gomila od / gledanje cvijeća] 
glavni grad,

skoro in sto tisuća

promatra cvijeće...

3. 見わたせば眺むれば見れば須磨の秋

miwataseba / nagamureba mireba / suma no aki

[gledati naokolo / promatrati gledati / Suma od jesen]

razgledava se

promatra se i gleda se

jesen u Sumi

4. 花盛り山は日ごろの朝ぼらけ

hanazakari / yama wa higoro no / asaborake

[cvijeće u punom cvatu / planina je uobičajeno od / zora]

vrhunac cvata

svakodnevan planinski

početak dana

5. 月のみか雨に相撲もなかりけり

tsuki nomi ka / ame ni sumō mo / nakarikeri

[mjesec samo ? / kišom sumo i / izostati]

samo mjesečina?

zbog kiše nema niti

sumo hrvanja.

\section{Označeno}


lako je jasno da oko ovdje iznesenih terminoloških dilema ne postoji konsenzus u Japanu, a još manje izvan njega, ipak je bjelodano da su usjek i usječnica nezaobilazno važni elementi poetike haikua. Dosad je bilo riječi o tim terminima uglavnom s obzirom na njihovu pojavnost u japanskoj poeziji, i to tijekom razdoblja Edo, iako treba napomenuti da i unutar tog vremena postoje izrazito velike razlike u poetici haikua, ne samo između različitih pjesnika i komentatora, već i u praksi pojedinih autora kao što je Bashō. U ovom dijelu teksta fokus će se proširiti na haiku kakav postoji danas kao globalni književni fenomen prisutan u većini zemalja na svijetu, a uvelike i u Hrvatskoj. Ipak, još uvijek glavni orijentir ostaje haiku u fiksiranom stihu nasuprot suvremenoj tradiciji haikua u slobodnom stihu.

lako unatoč raširenosti haikua u Hrvatskoj usjek i usječnica dosad nisu dobili teorijsku razradu kakvu zaslužuju, oba su termina svakako prepoznata u hrvatskoj haiku-praksi, o čemu uostalom svjedoče i antologije koje će se ovdje analizirati. Neizravan dokaz tomu je i mnoštvo prijevodnih inačica termina kireji koje se spominju u različitim paratekstualnim prilozima haikuima poput komentara ili eseja; pretragom interneta mogu se pronaći primjeri poput „rez”, „rezna riječ”, „stanka”, „prijelom”, „ritmička pauza”. Takvi su prijevodi obično uklopljeni u pragmatični kontekst upućivanja onih koji su zainteresirani za haiku u njegove zakonitosti kako bi ih oni mogli bolje razumijevati i eventualno sami pisati. Svi su načelno prihvatljivi kao doslovni prijevodi, no kao što je već istaknuto, problematično je što se njihovom uporabom ne ističe razlika između kire i kireji te što se iz njih ne da lako iščitati koliko su bliski mnogo poznatijem terminu cezure (osim eventualno pri korištenju „stanke”).

Ipak, jednom kada se čvršće uspostave osnovne značajke usjeka i usječnice, otvara se mogućnost za istraživanje njihovih različitih pojavnosti u pjesmama. Nažalost, ovdje nam neće od prevelike pomoći biti navedena Devidéova definicija usječnica kao usklika koji „posebno podcrtavaju boju osjećaja ili raspoloženja pjesnika pri opisanom događaju", i to iz najmanje tri razloga. Prvi i najbanalniji je taj što haiku ne mora opisivati događaj, iako je legitimno govoriti o haikuu kao književnoj vrsti specijaliziranoj za „male priče” (usp. Marshall 95). Drugi je razlog nekritičko izjednačavanje „pjesnika” s „lirskim ja” kao tekstualnim konstruktom o čijim nam je eventualnim osjećajima ili raspoloženjima ustvari jedino moguće govoriti budući da u većini slučajeva (načelno zapravo nikada) ne možemo ništa sa sigurnošću znati o pjesnikovu mentalnom stanju u trenutku 
nastanka i revidiranja pjesme. Treći je razlog blisko povezan s drugim, a tiče se osnovnih zahtjeva klasične poetike i jezičnih uzusa haikua, čija je posljedica izbjegavanje fiksne promatračke pozicije u pjesmi, pa čak i jasnog razlikovanja promatračkog subjekta od promatranoga objekta. Takvu perspektivno neodređenu poziciju haikua Devidé ispravno dovodi u vezu sa zen-budizmom (iako tu vezu vjerojatno i prenaglašava, kao i neki drugi proučavatelji; usp. Shirane, Traces 45), no budući da ne pravi razliku između usjeka i usječnice, već govori samo o potonjem, propušta spomenuti da koncept usjeka djelomice potječe iz te inačice budizma.

Općenitije govoreći, usjek je prisutan u japanskoj religiji i estetici i izvan haikua, primjerice u obliku „osnovne figure u zen-budističkoj školi Rinzai, što se pogotovo vidi u učenju zen-majstora Hakuina (1686. - 1769). Za Hakuina se cilj 'sagledavanja svoje vlastite prirode' može ostvariti samo ako se 'odsječe korijen života'." (Parkes i Loughnane) Ovaj citat iz Stanfordske enciklopedije filozofije referira se na korištenje usjeka i u uređivanju krajobraza i cvijeća (ikebana) te u drami nōa, a osvrće se dakako i na haiku, pri čemu se napominje da usječnica razdvaja jednu predodžbu od druge, ali istodobno je s njome i spaja. Ovdje nam je važan samo književni kontekst i stoga zenbudistički korijeni usjeka mogu ostati samo na napomeni, a za detaljniji opis usjeka mnogo nam je važnije istaknuti da su u tradicionalnom haikuu uobičajena tri oblika organizacije pjesme s obzirom na usjek.

Ponajčešći je oblik s jednim usjekom (i usječnicom) koji se nalazi na razmeđu dviju različitih predodžbi ili slika (predmeta) ili ideja ili tema, odnosno na razmeđu dviju polovica pjesama, bez obzira na to što one sadrže. Primjer je toga navedeni Bashōov haiku 1., u kojem usječnica „ya” uspostavlja odmak odnosno usjek između socijalnoga konteksta druženja uz sake (prva slika) i bljeska munje koji prati prirodnu pojavu (druga slika) koja se odvija nevezano uz zabavu. Usječnica pritom istodobno spaja ta dva fenomena između kojih ne postoji uzročno-posljedična veza u zajedničku sliku (iznenađenih? prestrašenih? nasmijanih?) lica pilaca pri odbljesku munje koju čitatelj treba aktualizirati upravo na mjestu usjeka. U drugom se tradicionalnom obliku haikua također pojavljuje usjek, ali u odnosu na samo jednu predodžbu (sliku, ideju, temu) i ističe jedan njezin dio u odnosu na cjelinu. Bashōov haiku 2. taj istaknuti dio smješta na sam kraj pjesme koja u cjelini prikazuje atmosferu i prirodu prijestolnice. Usječnica „kana” ovdje ne dijeli pjesmu na dva dijela jer se nalazi na samome kraju, što je ujedno primjer zašto termini poput „rez” ili „prijelom” 
nisu sasvim logičan prijevodni izbor, budući da u velikom broju slučajeva ništa ne „režu” niti „prelamaju” (iako ta nelogičnost postoji i u izvorniku). „Kana” se ovdje pojavljuje više u funkciji sintaktičkoga izdvajanja (umjesto razdvajanja) onoga što joj neposredno prethodi u posljednjoj trećini stiha, ali i u funkciji spajanja tog promatranja cvijeća sa semantičkim sadržajem prve dvije trećine pjesme koja, kao i prethodna, time povezuje u jedno čovjeka i prirodu.

Treći uobičajen oblik haikua ne sadrži ni usjek ni usječnicu i čitava pjesma je u tom slučaju kompaktna i ne ističe se nijedan njezin dio. Ovakve su pjesme češće od 20. stoljeća naovamo, pogotovo izvan Japana, a u klasičnim primjerima uglavnom je moguće naći barem naznaku usjeka. Tako je u primjeru 3. logično mjesto za usjek između druge i posljednje trećine, odnosno između dijela pjesme koji sadrži samo glagole i dijela koji sadrži samo imenice (i posvojnu česticu „no”). Ipak, budući da su glagoli u kondicionalu, koji podrazumijeva da se drugi dio rečenice izravno odnosi na prvi („kada se gleda, onda se vidi jesen”), te s obzirom da je druga trećina za jednu moru dulja (pa pjesma u hrvatskom prepjevu ima hiperkatalektičan drugi redak), donekle se poništava čitateljski refleks za učitavanjem usjeka i stoga se može utvrditi da ga u ovoj pjesmi ni nema. Kako vidimo, postojanje usječnice nije predmet interpretacije, ali postojanje usjeka jest, uključujući i njegovu funkcionalnost, odnosno je li više u službi spajanja ili razdvajanja različitih dijelova haikua.

Uz ova tri najčešća oblika japanskog haikua logično se pridaje i četvrta opcija, u kojoj haiku ne sadrži nijednu klasično određenu usječnicu, ali unatoč tome sadrži usjek. U Bashōovom haiku 4. nema usječnice, ali usjek se sam nameće nakon petoga sloga (u prepjevu je označen prazninom između prvoga i drugoga retka), odnosno između dvije imenice u pjesmi koje nisu odijeljene nekom funkcionalnom česticom poput „ha” ili „no”. Slično kao u haikuu 2., i ova pjesma donekle funkcionira kao sinegdoha jer predstavlja manji dio (cvijeće u punom cvatu) cjelovite predodžbe (zora u planini), a razlika je u tome što ovdje nema želje za snažnijim isticanjem toga manjeg dijela, koji bi time preuzeo na sebe glavno semantičko težište čitave predodžbe. Također, za razliku od 4. primjera, ne postoji gramatička potreba da čitava pjesma bude kompaktno povezana, pa i zbog toga možemo u njoj spremno prepoznati usjek.

Naposljetku, u klasičnoj poetici vjerojatno se najrjeđe nalaze haikui s više od jednoga usjeka, što znači da usječnice istodobno spajaju i prekidaju pjesmu na barem dva mjesta. Kada se ipak pojavljuju, usječnice se u principu ne ponavljaju, kao u primjeru 5., koji sadrži česticu koja izražava 
pitanje („,ka”) i glagolski nastavak („keri”) koji može izražavati više toga, ali ovdje se može shvatiti kao da označava iznenađenost naglom spoznajom. Prema tome, u pjesmi se usječnicama razdvajaju dvije sporedne pojave (mjesec i sumo) od primarne i u središte pjesme pozicionirane predodžbe kiše koja ih onemogućuje i time in stavlja u podređen položaj. K tomu, slično kao u primjerima 1. i 2., te ako „mjesec” shvatimo kao omiljenu japansku zabavu promatranja mjesečine (poput ispijanja sakea ili promatranja cvijeća), radi se ponovno o dvije društvene aktivnosti koje su metaforički „presječene” prirodnom pojavom. Usječnice pritom same po sebi sadrže različitu „snagu” razdvajanja i povezivanja, pri čemu je druga u ovom primjeru „snažnija” od prve, što elegantno podcrtava emociju iznenađenja uslijed nemogućnosti promatranja suma nakon samorazumljivog gubitka mogućnosti promatranja mjesečine.

Spomenuto dvojno svojstvo usjeka da ujedno spaja i razdvaja ključno je za interpretaciju svakoga haikua u kojem se pojavljuje pa mu treba posvetiti više pozornosti. Ono donekle podsjeća na funkciju rastavnih veznika, koji semantički razdvajaju i sintaktički spajaju dijelove jezičnog iskaza, no ta usporedba vrijedi samo donekle jer usječnice nemaju toliko precizno značenje, a osim toga se, za razliku od veznika, rutinski pojavljuju i na kraju cjeline (stiha). No, struktura haikua u kojoj se dvije nepovezane stvari, slike ili predodžbe dovode u vezu može se usporediti i s jednim mnogo tradicionalnijim i važnijim terminom zapadnjačke poetike, koji je istodobno jedna od polazišnih točki suvremenih razmišljanja o jeziku uopće, a riječ je o metafori.

U članku koji se ustvari bavi haiku-poezijom u sklopu poziva na interdisciplinarnu suradnju znanosti o književnosti i psihologije u svrhu proučavanja kreativnosti, Blasko i Merski primjećuju da se u pregledima haiku-poezije, pogotovo izvan Japana, poriče postojanje metaforičnosti i obeshrabruje upotreba metafore kod budućih pjesnika. Kao primjer autori citiraju Yasudin jasan stav:

'[m]etafora [je] uvijek smetnja haiku pjesniku.' Osnovni argument za to jest da bi metafora pomutila predodžbe, zakrila dublje značenje i uništila totalno objektivnu prirodu haikua .... No, u istome dahu u kojem nam se govori da pod svaku cijenu trebamo izbjegavati upotrebu metafore, također nam se govori da bismo u dobrom haikuu trebali vidjeti supostavljanje dva neslična elementa ili slike koji bi čitatelja trebali dovesti do novoga, živopisnog uvida ili iskustva. Ovo se čini sasvim slično definiciji metafore i mnogi haikui posjeduju jasnu metaforičnu kvalitetu. (40) 
Autori članka objašnjavaju da nelogičnost toga stava - metaforu treba izbjegavati, ali je zapravo svaki dobar haiku sadrži - proizlazi iz zastarjelog, tradicionalnog poimanja metafore prema kojem je riječ isključivo o retoričkoj ili književnoj figuri koja se upotrebljava kao dodatak ili potkrepa osnovnoj misli. Nasuprot tome, u lingvistici i teoriji književnosti od kraja prošloga stoljeća prevladava mišljenje da je metafora ustvari „jedno od prirodnih sposobnosti ljudskoga uma ... Metafora je za naš um temeljna jednako kao što je disanje za tijelo, i jednako je automatska. Stoga, ako je cilj haiku-pjesnika (i pjesnika općenito) da izmami nove uvide u čitateljevu razumijevanju ljudskosti, tada se upotreba metafore gotovo ne može izbjeći." (42)

Učestalost metaforičnog mišljenja u haikuu ide ruku pod ruku s učestalosti usjeka, budući da se upravo usjekom omogućuje povezivanje, odnosno „supostavljanje dva neslična elementa ili slike”. lako Blasko i Merski to ne navode, ideja supostavljanja različitih ideja u cjelinu (slično kao „objektivni korelativ”) ima svoj pandan u klasičnoj japanskoj poetici haikua u terminu „toriawase” (取合わせ, „kombiniranje” ili „slaganje”). Koliko je ta ideja važna za haiku anegdotalno svjedoči i činjenica da je jedan suvremeni časopis posvećen haiku-poeziji uzeo naziv Juxtapositions odnosno „supostavljanja”. Iz tog časopisa ovdje je već citiran jedan članak Harua Shiranea, koji se na drugom mjestu detaljnije bavi supostavljanjem, ističući da se ono postiže usječnicom koja u hokku (što se odnosi i na haiku) stvara dinamičku strukturu koja je pandan općoj strukturi renge. U tom pogledu Shirane, koji je sasvim uvjeren da je haiku „poput sve poezije snažno metaforičan” ( Traces 46), ponavlja mišljenje praktičara poput Bashōa ili Seisensuija, ali ga i proširuje pozivajući se na distinkciju Philipa Wheelwrighta između „epiforijskih” i „dijaforijskih” metafora (što ne treba brkati s istoimenim figurama dikcije; usp. Bagić 80, 108-10). Prva vrsta metafore „'izražava sličnost između nečega što je relativno dobro ili konkretno poznato (semantički prijenosnik [vehicle]) i nečega što je, iako vrjednije ili važnije, manje poznato ili opskurnije (semantički sadržaj [tenor]).' Nasuprot tome, dijafora stvara nova značenja isključivo kroz supostavljanje." (Shirane, "Matsuo" 100)

Shirane napominje da svaka pojedina metafora nikada (isključivo) ne pripada samo obliku epifore ili dijafore, već da je uvijek bliže ili dalje jednom od ta dva pola. Isto vrijedi, kao što smo vidjeli, i za funkcije spajanja i razdvajanja koje sadrži usjek. Ako su dvije predodžbe koje se pojavljuju u haikuu kognitivno i leksički udaljenije, tada je riječ o „dijaforijskoj” metafori supostavljanja ( 
toriawase) i u usjeku je naglašenija funkcija razdvajanja. Ako su dvije predodžbe koje se pojavljuju u haikuu kognitivno i leksički bliže, tada je riječ o „epiforijskoj” metafori sličnosti i u usjeku je naglašenija funkcija spajanja. Sukladno tome, čitatelj haikua će prilikom čitanja morati više poraditi na spajanju disparatnih predodžbi u slučaju kada se radi o dijafori (toriawase), odnosno na isticanju određene distinkcije kada se radi o epifori. Shirane kao primjer takvog funkcioniranja metafore i usjeka uzima jednu od najpoznatijih Bashōovih pjesama, no nama ovdje može poslužiti i slabije poznat haiku iz primjera 4. U toj pjesmi nema usječnice, ali možemo govoriti o usjeku ako je tumačimo kao epiforu, pri čemu cvijeće u cvatu služi kao relativno dobro poznat prijenosnik koji tumači sadržaj planinskoga jutra. Takvo tumačenje počiva na činjenici da je iz ljudske perspektive osjetilima mnogo lakše obuhvatiti i spoznati relativno ograničenu predodžbu cvijeća nego mnogo veću i protežniju predodžbu čitave planine. lako se planina u pjesmi pokazuje kao „vrjednija ili važnija”, istodobno nam je zbog ograničenih sposobnosti spoznaje „manje poznata ili opskurnija”, a usjek nužan kako bi tu nesklapnost istovremeno istaknuo, premostio, ali i ilustrirao.

Dotični je usjek teško protumačiti kao supostavljanje jer, iako nije eksplicitno navedeno, logično je očekivati da se radi o planinskom cvijeću i da te dvije slike zajednički funkcioniraju kao jedna prostorna i vremenska cjelina. Isto vrijedi i za 3. primjer, u kojem s jedne strane ne možemo govoriti o postojanju usjeka zato što je gotovo nemoguće u međuodnosu tih slika prepoznati supostavljanje ili dijaforu. No, u toj pjesmi teško bi bilo prepoznati i epiforu zato što se između glagola koji opisuju gledanje u prvih 13 slogova (prva dva retka) i onoga na što se oni odnose (jesen u Sumi) ne uspostavlja hijerarhija vrijednosti i važnosti: jedno je uvjetovano drugim i obje predodžbe postoje u cjelini. Pozivajući se na Romana Jakobsona, Shirane primjećuje da se prisutnost epifore u haikuima može povezati s metonimijskim principom (os kombinacije), dok se prisutnost dijafore može povezati s metaforičkim principom (os selekcije). Konkretno, dvije polovice pjesme koje su podijeljene usjekom nalaze se ili u nekoj vrsti kauzalnog odnosa (os kombinacije, epifora), gdje jedna polovica uvjetuje drugu, ili u nekoj vrsti supostavljenog odnosa (os selekcije, dijafora), gdje obje polovice „metaforički odzvanjaju jedna o drugu”. Prema tome, upravo se s obzirom na interpretaciju usjeka čitav haiku iščitava kao „metonimijski” ili „metaforičan” (Shirane, "Matsuo" 101). Budući da je već istaknuto kako primjer 4 slijedi logiku sinegdohe, što je podvrsta metonimije, do čitave je interpretacije - „planinsko cvijeće na vrhuncu cvata nezaobilazan je dio 
specifičnog doživljaja početka dana na planini” - dovelo metonimijsko (epiforijsko) čitanje usjeka, odnosno dinamike međuodnosa predodžbi za koju je on zaslužan.

Radi dodatnog pojašnjenja i ilustracije mogućnosti ovakvog tumačenja usjeka s obzirom na nijanse koje omogućuje, osvrnimo se i na preostala tri primjera iz Bashōa. U primjeru 5, prva usječnica „ka” označava usjek koji spaja prvu trećinu stiha s drugom u obliku pitanja i odgovora - „Zašto se ne vidi mjesec? Zbog kišnih oblaka” - dok druga usječnica „keri” označava jaz između mogućnosti da se promatra natjecanje u sumo-hrvanju i činjenice da pada kiša, razdvajajući time drugu i posljednju trećinu stiha. Prema tome, ova pjesma drži se metonimijskog principa uzroka i posljedice, samo što je u prve dvije trećine prisutna gotovo isključivo epiforija, dok je na samome kraju veći udio dijafore jer promatranje suma nije toliko neposredno povezano uz kišno vrijeme kao promatranje mjeseca.

Preostala dva Bashōova primjera donekle su jednostavnija s obzirom na jedinstvene i precizne usjeke i usječnice. Primjer 2 najjednostavniji je jer usječnica mnogo snažnije spaja predodžbu koja joj neposredno prethodi (promatranje cvijeća) s ostatkom pjesme (prijestolnica) nego što bi in razdvajala, pa je stoga i epifora mnogo prisutnija nego dijafora i nameće se metonimijsko čitanje čitavoga haikua. U primjeru 1, usječnica „ya” također se pojavljuje na jednom od tri očekivana mjesta i stoga predstavlja sintaktičku sponu s onime što slijedi na sličan način kao što to čini cezura. No smisao onoga što slijedi poprilično odudara od prethodnih riječi i stoga je funkcija razdvajanja ovoga usjeka snažnija, ali ne i pretjerano jaka jer je ublažena cirkularnom kauzalnom povezanosti snježnog nevremena i munje u prvoj i posljednjoj riječi stiha; ipak, usjek je ovdje dovoljno jak da stvori dojam dijafore.

Za potrebe ovoga rada razmatranje složenosti usjeka zaustavit će se na još jednom njegovom aspektu, koji također proizlazi iz kognitivne lingvistike. Naime, kao što je primijećeno - haiku se općenito može tumačiti kao ogledan primjer univerzalnoga metaforičkog načina mišljenja koji je jezično uobličen u stihovani izraz, i tako je doveden u vezu i s konceptom pretapanja (engl. „blending”). Uobičajeni smisao te riječi koristi primjerice R. H. Blyth u komentaru jednoga haikua kojem bi glavna vrlina bila „pretapanje, kroz zvuk i sliku, mjeseca i grana i opadajućega cvijeća” (268). No, Masako Hiraga u članku posvećenom kognitivnom pristupu haikuu pojašnjava da se radi o modelu koji se temelji na najmanje četiri „konceptualne projekcije” umjesto uobičajene dvije 
domene koji se u nešto drukčijim oblicima pojavljuju kao osnovice različitih teorija metafore (primjerice, kao prijenosnik i sadržaj). Prilikom zamišljanja određenog sadržaja stvaraju se dva „ulazna prostora” (engl. „input spaces”) u kojima se nalaze svi subjektu dostupni podaci koji ih pomažu konceptualizirati. Usto, uz svaku domenu stvara se i zaseban prijelazni prostor (engl. „middle space”) koji sadrži temeljne podatke iz osnovnih domena, ali i poseban prostor unutar prijelaznih prostora u kojem se inače nepovezani podaci iz obje domene spajaju i na taj način „pretapaju” u treću vrstu novih podataka i spoznaja. Autorica zatim ističe prednost takvog modela u tumačenju haikua upravo s obzirom na funkcije supostavljanja i usječnice, koji označavaju uspostavu prostora pretapanja u pjesmi (Hiraga 465-66).

Kao i mnogi drugi autori koji se bave haikuom, Hiraga oprimjeruje svoj pristup na Bashōovim pjesmama i zaključuje da je za njegovu poetiku karakteristično korištenje raznolikih i inventivnih ulaznih prostora. Njihove granice u svakom se haikuu određuju primarno pomoću usječnice i rjeđe pomoću igara riječima (kakekotoba), ovisno o tome koji od ta dva elementa sadrži pojedina pjesma. lako Hiraga ne spominje taj termin, iz svega navedenoga proizlazi da se prijelazni prostor može konceptualizirati kao ranije spomenuti ma, metaforički međuprostor koji se stvara upravo usjekom (vidi Wilson; Višnjić Žižović i Toyota; Škopljanac). Na takav zaključak pogotovo navodi činjenica da u koncepciju ma ulazi i psihološko značenje, a upravo njega kao važan element pretapanja ističe Hiraga. Pritom ne treba brkati „lokalno pretapanje”, unutar svakog pojedinog dijela stiha određenog usjekom, od pretapanja koje se događa „unutar” usjeka, odnosno na razini čitave pjesme. Analizirajući jedno takvo lokalno pretapanje u pjesmi čija se prva trećina sastoji od koncepata „proljeća” i „putovanja”, autorica primjećuje kako nijedan od ta dva ulazna prostora ne implicira tugu, odnosno tugaljiv ugođaj kojim odiše haiku u cjelini (u Devidéovu prepjevu: „Proljeće minu - / u oku ribe suza / i ptice plaču.”; Japanska 134). No, upravo „[u] pretapanju se odlazak prožima sa završnom etapom proljeća, što nas navodi da tumačimo tugu oko rastanka jednakoj tuzi oko uminuća toga godišnjeg doba." (Hiraga 470)

Haiku se, dakle, odlikuje jedinstvenom poetskom strategijom prema kojoj se emocionalni sadržaj i ton pjesme „skrivaju” između koncepata u ulaznim prostorima, a koji se pak najčešće sastoje od izravnih opisa predmeta, pojava i slično. Stoga, ako se podsjetimo Devidéove definicije usječnica kao usklika koji „posebno podcrtavaju boju osjećaja ili raspoloženja pjesnika pri opisanom 
događaju”, može se dodati da je to točno, ali da sama pojava „osjećaja ili raspoloženja” ovisi o pretapanju različitih elemenata pjesme u njezinim pojedinim dijelovima, a pogotovo na usjeku. Pritom ono što je karakteristično za model pretapanja, i što Hiraga podcrtava kao veliku prednost u analizi haikua, jest da „[z]a razliku od jednosmjerne konceptualne projekcije standardnoga modela, koja određuje smjer od izvora [prijenosnika] prema meti [sadržaju], novi model pokazuje da je konceptualna projekcija neizravna i može se kretati u bilo kojem smjeru između ulaznih prostora." (466)

Ukoliko se zadržimo na prototipnoj situaciji jednog usjeka u kojem se događa pretapanje na razini čitave pjesme, u praksi to znači da oba dijela pjesme mogu podjednako utjecati jedan na drugi, bez obzira na to kakva se hijerarhija vrijednosti i važnosti među njima uspostavlja. Ovo je vrlo važno za haiku zbog već spomenutog izjednačavanja subjekta i objekta, što poništava očekivanu agentivnost živih bića (pogotovo čovjeka) nasuprot neživih bića i koncepata. U primjeru koji navodi Hiraga to znači da odlazak proljeća izaziva tugu kod riba i ptica, ali i da se njihova tuga pretapa s inače emocionalno neutralnom pojavom izmjene godišnjih doba, koja stoga postaje tužna sama po sebi. Sličan se učinak slobodnog kretanja konceptualne projekcije u bilo kojem smjeru oko usjeka kao središta može iščitati i u bilo kojem od pet gore navedenih Bashōovih haikua iz Barnhillova izbora. No za zaokruživanje ovog aspekta usjeka od analize možda će bolje (i svakako prikladnije) poslužiti još jedna metafora, ovaj put iz konceptualne projekcije jednog američkog pjesnika: „Lee Gurga bilježi da se procijepi [engl.: „gaps”] uspješnog haikua moraju proračunati pažljivo kao i za [automobilske] svjećice - ako su predodžbe previše udaljene, nema iskre, a ako su preblizu (što znači da samo ponavljaju prvu predodžbu), također nema iskre .... No, kada je procijep napravljen baš kako treba, čitatelj dobiva inspiraciju da poveže dvije predodžbe i da ispuni procijep značenjem - eto iskre.” (Hiraga 102) Proizvesti tu „iskru”, odnosno angažman čitatelja, zadatak je svakoga autora haikua, pa nakon terminološkog i književnoteorijskog obrazlaganja usjeka s obzirom na okolnosti u domaćoj literaturi preostaje još pokazati kako to „iskrenje” funkcionira i u domaćoj praksi.

\section{Analiza korpusa}


Nekoliko je razloga zbog kojih će analiza haikua koja slijedi biti provedena kombinacijom računalne obrade i subjektivne interpretacije ${ }^{[1]}$ Prvi i osnovni razlog je što računala omogućuje uvide do kojih je pojedincu izrazito teško ili nemoguće doći, a koji se mogu pokazati korisnima za razumijevanje književnih fenomena kao što je usjek (usp. statistički pristup haikuima u Long i So). Drugi je razlog taj što se u današnjoj humanistici sve više nameće imperativ objektivnog i empirijskog proučavanja tradicionalno kritički poimanih predmeta kao što je književnost, što je donekle opravdano, a donekle nije, no svakako zahtijeva odgovor i angažman nekog tipa, makar i ignoriranjem (vidi Schmidt; Guillory; Golumbia). Treći je razlog specifičnost haiku-poezije koja se, zbog svojih relativno strogih formalnih pravila i svoje kratkoće, može podvrgnuti računalnoj analizi na način koji uzima u obzir njezine različite specifičnosti, recimo sadržaj riječi prije i poslije usjeka. Četvrti i posljednji razlog jest što ovakva analiza omogućuje bavljenje velikim brojem zasebnih tekstova, što je ujedno jedna od osnovnih premisa „udaljenog čitanja”. Naravno, u slučaju haikua time se ne omogućava ništa što nadilazi ljudske sposobnosti budući da je, za razliku od nekih drugih književnih vrsta poput romana, moguće pročitati (i napisati) tisuće haikua dnevno. Ipak, na ovaj način se osigurava da se svim tim tekstovima barem načelno pridala jednaka pozornost u prvom sloju (računalne) analize, što je osobito važno jer je riječ o antologijskim tekstovima, koji su po definiciji vrijedni osobite pažnje.

Korpus se sastoji od tri knjige: Antologija hrvatskoga haiku pjesništva (u nastavku: AHHP), Nepokošeno nebo: antologija hrvatskoga haiku pjesništva 1996-2007. (u nastavku: NN 1) i Nepokošeno nebo 2: antologija hrvatskoga haiku pjesništva 2008-2018. (u nastavku: NN 2). Prva antologija sadrži pjesme nastale do 1995., pa je iz izbora godina u naslovu druge dvije očito da se one nastavljaju jedna na drugu i tako tvore antologijsku cjelinu koja obuhvaća praktički čitavu produkciju haikua na hrvatskom jeziku do danas. Gotovo sve pjesme tiskane su u tri standardna retka, a pravopisne norme variraju od pjesme do pjesme, što primjerice znači da ponekad svi redci započinju velikim slovom ili da pjesma završava točkom ili nekim drugim interpunkcijskim znakom, no to nije uvijek slučaj.

Podatak o tiskanju u tri retka ovdje je relevantan iz dva razloga, od kojih je prvi to što dovodi do opservacije da je formalizacija trodijelne podjele monostiha haikua apsolutno prevladala u domaćem pjesništvu na način da svaki od ta tri dijela zadobiva još veću neovisnost. Time sve 
pjesme doslovno zadobivaju drukčije dimenzije (poput desne vertikale) nego da su tiskane u jednom retku, što ima i ozbiljne posljedice po analizu pomnim čitanjem (vidi npr. Kolar). Drugi razlog zbog kojeg je grafička dosljednost relevantna jest taj što se formalnom podjelom na tri retka olakšava udaljeno čitanje, odnosno računalna analiza onoga što se može nalaziti na kraju svakoga od redaka, a u ovome slučaju to su usječnice. Konkretno, u prvome koraku analize pomoću programskoga jezika Python iz svih je pjesama izdvojen svaki prvi i drugi redak koji je završavao jednom od usječnica koje su definirane kao interpunkcijski znakovi. Navedenih je znakova bilo ukupno $9(! ?--\ldots ;:$, , ) te iako nijedan od njih nema direktan prijevodni ekvivalent na japanskom jeziku, ipak neki od njih zauzimaju vrlo slično semantičko polje kao i kireji; na prvom mjestu je svakako „ka” koji se rutinski prevodi upitnikom, zatim „zo” i „ya”, koji se u većini slučajeva mogu prevesti uskličnikom odnosno crticom (ili spojnicom), pa i „kana” koji se može prevesti trotočkom ili točkom na kraju stiha.

Budući da se zbog neujednačenosti pravopisne norme između tri knjige nije moglo sa sigurnošću odrediti je li interpunkcija na kraju trećega retka signal za usječnicu ili za poštivanje pravopisa, potencijalne usječnice na kraju trećega retka nisu uzete u obzir pri analizi, iako ima više pjesama u kojima se pojavljuju kao ekvivalent za „kana”. Između tridesetak pjesama koje se preklapaju odnosno koje se ponavljaju između AHHP i oba NN mogu se izdvojiti tri koje ilustriraju ovaj i druge probleme u računalnoj analizi:

6.1. U pećinama / grobovi prošlog rata. / Vani bombardiranje! (AHHP, 62)

6.2. U pećinama / grobovi prošlog rata. / Vani bombardiranje. (NN 1, 22)

7.1. Uzimam bombu, / vraćam je u kutiju, / pa je uzimam... (AHHP, 63)

7.2. Uzimam bombu. / vraćam je u kutiju, / pa je uzimam ... (NN 1, 23)

8.1. Proguta ribu / galeb opakih očiju, / bijel i nevin. (AHHP, 270)

8.2. Proguta ribu / galeb opakih očiju / bijel i nevin. (NN 1, 278 i NN 2 366)

Razlike su vrlo male, ali u književnosti načelno ništa nije prepušteno slučajnom izboru jezičnog materijala, pogotovo u poeziji, što još više dolazi do izražaja u tako kratkim oblicima kao što je haiku. Čak i ako ostavimo po strani usjek, promjene u interpunkciji neznatno mijenjaju ritam riječi u pjesmama 7 i 8, ali takva se razlika snažnije osjeti čim je pjesma kraća. Ako razlike analiziramo s 
obzirom na usjek, tada pjesma 6.1. ima dva usjeka (usječnice su točka i uskličnik), dok pjesma 6.2. ima samo jedan usjek, a usječnica je samo prva točka jer se završna točka u tom slučaju ima tumačiti kao ustupak pravopisu; zbog ovakvog i drugih sličnih slučajeva, interpunkcija na kraju pjesme nije se uzimala u obzir. Usto, prva inačica (6.1.) snažnije naglašava kontrast „unutra”/,vani” i prenosi mnogo emocionalniji, šokantan ton, te postiže gradaciju kakva je karakteristična za dva usjeka (kao u primjeru 5). Druga je inačica (6.2.) više umjerena i odmjerenoga tona, te ne ostavlja dojam da bombardiranje vani ima previše veze s onime što je unutra, kao da se ne događaju nužno istovremeno.

Slično tome, 7.1. i 7.2. mogu se tumačiti kao haikui koji završavaju usjekom, ali točka nakon 5. sloga u 7.2. još je bolji „kandidat” za usječnicu jer nije sintaktički nužna, kao što potvrđuje zarez na njezinu mjestu u 7.1. Da stvar bude još kompliciranija, budući da se radi o istoj predodžbi, dapače o jednom pokretu koji se zrcalnom simetrijom odvija u obje polovice pjesme (središnji 9. slog ujedno je i najkraća riječ u pjesmi, „u”), usjek u interpretaciji može i sasvim izostati, a ukoliko se postavlja na kraj, onda „produljuje” trenutak haikua implicirajući da se opisana radnja ponavlja unedogled. Takva dilema pospješuje višeznačnost pjesme, a time i njezin estetski učinak na čitatelja, no otežava analizu, pogotovo računalnu. U primjeru 8.1. ta pravopisna uloga ipak izostaje jer je zarez nakon druge trećine pjesme potpuno opcionalan, što bi upućivalo na njegovu snažnu razdvajačku funkciju ukoliko se shvati kao usječnica. Kao i u pjesmi 6, usjek na tome mjestu naglasio bi kontrast „unutra”/,vani” u prvom i drugom dijelu pjesme, s tom razlikom što se ovdje radi o razlici pretpostavljenog moralnog ustrojstva ptice - koja u tradiciji haikua ima agentivnost čovjeka, čemu svjedoči Bashōov haiku koji navodi Hiraga - i njezinog fizičkog izgleda koji odudara od okrutnosti. Dakako, u tradiciji zapadnjačke književnosti životinje načelno nemaju takve karakteristike (osim u basni i još nekim ograničenim slučajevima), pa se pjesma treba iščitati kao jedna slika kakvom je vidi lirsko ja. U tom je slučaju inačica bez usjeka (8.2.) pogodnija za „zapadnjačku” interpretaciju singularne perspektive negoli za „istočnjačku” interpretaciju neodređene perspektive, što pokazuje koliko smještanje usjeka u bitnome utječe na opći doživljaj haikua.

lako je stoga bjelodano da opisan pristup tekstovima već u prvome koraku nije savršeno precizan, ipak nam relativno precizno daje pregled nad time koje se usječnice i koliko često koriste u 
hrvatskim haikuima. Također, kao što pokazuju primjeri 6, 7 i 8, takav pristup jasno prikazuje razlike koje bi inače bilo mnogo teže uočiti u mnoštvu tekstova odnosno znakova kakvima obiluju obimniji i reprezentativniji korpusi. Što se tiče ovog korpusa, on sadrži 7084 pjesme (1126 u AHHP i 5958 u oba NN). Iz takvog broja tekstova računalno se može iščitati popriličan broj zanimljivih podataka, recimo o broju slogova u svakome retku ili o najučestalijim riječima i pojmovima, no ovdje će pozornost biti isključivo na usjeku.Tablica 1

\begin{tabular}{|c|c|c|c|c|c|c|c|c|c|}
\hline & $!$ & $?$ & - & - & $\ldots$ & ; & : & . & , \\
\hline AHHP & 15 & 4 & 0 & 78 & 19 & 20 & 41 & 338 & 68 \\
\hline NN $1 / 2$ & 17 & 8 & 385 & 231 & 107 & 30 & 101 & 852 & 201 \\
\hline sve & 32 & 12 & 385 & 309 & 126 & 50 & 142 & 1190 & 269 \\
\hline
\end{tabular}

Distribucija 9 potencijalnih usječnica podatak je koji najizravnije upućuje na prisutnost usjeka u antologijskim haikuima i ovdje je izražena u tabličnom obliku (Tablica 1). Usječnice su pritom poredane otprilike s obzirom na njihovu dekontekstualiziranu „snagu”, odnosno s obzirom na vjerojatnost da dotični interpunkcijski znak, koji se pojavljuje na kraju jednog od prva dva retka u pjesmi, doista ima funkciju usječnice, a da nije tek (ili samo) posljedica pravopisne norme ili želje za lakšim razumijevanjem teksta. Takav poredak dakako nije moguće preskriptivno razložiti, u smislu da recimo uskličnik mora predstavljati najsnažniji usjek u tkivu haikua i da je njegova pojava uvijek signal da se radi o usječnici, no s deskriptivnog stajališta s velikom sigurnošću možemo tvrditi da prvih 7 interpunkcijskih znakova u tablici (od uskličnika do trotočke) doista predstavlja usječnice. Isto tako, kao što smo vidjeli u primjerima 7 i 8 , točka i (pogotovo) zarez lako se mogu protumačiti kao danak pravopisu, što nam potvrđuje i njihova učestalost: točka je uvjerljivo najzastupljeniji znak, ali nije svaki put u ulozi usječnice. Crtica (-) i spojnica (-) ustvari se trebaju računati kao jedan znak budući da se u AHHP isključivo koristi potonji, dok se u NN 1 i NN 2 naizmjenično koriste oba, što je posljedica neujednačenosti norme, a ne pokušaj da se različitim znakovima više naglasi svojstvo usječnice da razdvaja ili spaja.

Sposobnost horizontalne crte - bez obzira kako se zove ili koje je duljine - da konotira obje glavne funkcije usjeka očigledno je od velike koristi hrvatskim haiku-pjesnicima i stoga je njihov prvi izbor u označavanju usjeka, pojavljujući se u otprilike $10 \%$ svih pjesama. Tipičan je primjer 9: „Dva drvena križa - / Tjedan dana nakon muža / umrla žena." (AHHP, 83). Usječnica razdvaja i spaja dvije predodžbe, konkretnu i apstraktnu, koje se međusobno nalaze u metonimijskom odnosu 
(groblje i smrt). Riječ je stoga o epiforijskoj metafori, a u usjeku se ostvaruje pretapanje kojim se osobnosti bračnoga para svode na dva pravilna i gotovo identična oblika, naglašavajući time njihovu povezanost i postojanost. Također, slično kao u primjeru koji navodi Hiraga, pretapanje u usjeku priziva osjećaje tuge, patnje i gubitka s kojima se mogla suočiti supruga nakon smrti muža. Radi se inače o Devidéovoj pjesmi koja usječnicu koristi relativno uspješno, što pokazuje da je terminom baratao u praksi.

Identificiranje usječnica na kraju redaka ne uzima u obzir i nekoliko desetaka haikua u kojima se crtica i spojnica pojavljuju na poziciji usred jedne od trećina pjesme, a ne između njih. Takva praksa postoji i u klasičnim japanskim haikuima, a u hrvatskim primjerima ima različite varijacije:

10. Nakon zvona / - muk. / I dalje glasovi s ulice. (AHHP, 69)

11. Preko zida / vise prezrele smokve. / Na cipeli - džem. (NN 2, 314)

12.1. Uz potok - magla. / Vrhovi jablanova - / lebde u zraku! (AHHP, 243)

12.2. Uz potok - magla. / Vrhovi jablanova / lebde u zraku (NN 1, 239)

Pjesma 10 je primjer smjele i maštovite varijacije zbog razbijanja simetrije haikua s obzirom da je središnja trećina kraća od preostale dvije, umjesto obrnuto. No, ono što eksperiment čini uspješnim jest korištenje usječnice na početku drugoga retka, čime njegova kratkoća i odsječ(e)nost dodatno dolaze do izražaja. Time se omogućuje i da usjek dodatno naglasi supostavljanje predodžbe prostora u kojem se čuje zvono (škola? crkva?) i koji je doslovno i metaforički zatvoren (strogim normama) uz prostor ulice koji je s druge strane doslovno i metaforički otvoren (sloboda govora). Pjesma 11 također iskazuje određenu inovaciju u odnosu na japanski haiku budući da se drugi usjek (označen crticom) koristi kao pandan japanskom usjeku na samome kraju stiha. Ova pjesma iskazuje i tendenciju koja se ovdje zbog manjka prostora može samo naznačiti, a to je da hrvatski haikui češće od klasičnih japanskih haikua sadrže dvije usječnice. U dotičnom primjeru drugi je usjek ustvari nepotreban jer se pretapanje dvije predodžbe smokvi (vitalnih i pregaženih) sasvim očekivano i učinkovito može odvijati na usjeku označenom točkom. Čini se da je autorica željela dodatno poentirati, no takva vrsta isticanja za haiku je suvišna jer ponavlja istu predodžbu bez varijacije kakvu možemo vidjeti recimo u primjeru 5. U tom smislu još je više problematična pjesma 12, što je vidljivo i iz uredničkih i/ili autorskih intervencija između dvije inačice. U prvoj su čak četiri 
usječnice i usjeka, po jedno na svakom interpunkcijskom znaku, a da pjesma pritom ne nudi nikakvo bogatstvo predodžbi koje bi takav smion postupak moglo opravdati. U drugoj varijanti ostavljene su samo usječnice u prvoj trećini, koje baš kao u prethodna dva primjera okružuju i time osnažuju samo jednu riječ. No za razliku od primjera 10, ovdje nema opravdanja da se inače dosjetljivo zamišljena cjelovita predodžba jablana u magli prenaglašeno „siječe”, s obzirom na to da magla takvu sliku dočarava na mnogo suptilniji način.

Budući da se do svih dosadašnjih zaključaka moglo doći i „ručnim” prebrojavanjem, dosad prikazana analiza korpusa nije sasvim zadovoljila prvi ranije naveden razlog da se uopće primijeni, a to je stjecanje uvida koji su inače nedostupni. Ipak, postojanje vektorskog modela riječi za hrvatski jezik omogućuje i takav pristup, dakako opet u tandemu s kritičkim opservacijama. Vektorski modeli riječi omogućuju usporedbu danih riječi s obzirom na njihovu bliskost u kontekstu i mogu se izraziti primjerice numeričkom vrijednošću od 0 do 1, pri čemu će riječi koje se u nekom korpusu često pojavljuju jedna uz drugu imati visoku vrijednost i obrnuto. Na primjer, uz riječ „ljeto” u odabranom se modelu (Word2Vec) najučestalije pojavljuju riječ „proljeće” i „jesen”, dok je riječ „zima” na petom mjestu: antonimska je poveznica učestala u kontekstu, pa su te dvije riječi blisko povezane u nizu tekstova, iako su semantički udaljene. Takvo se modeliranje onda može proširiti i na veće skupine riječi, a u književnoj analizi sličan je vektorski model nedavno oproban u analizi dugih i kratkih pripovjednih proznih oblika, pri čemu je pokazano da kratke priče na početku i kraju teksta sadrže rečenice koje su više bliske nego što je to slučaj u romanima („Computational Approaches to the Short Story", predavanje održano pri Stanford Literary Lab 23. travnja 2020.). Primijenimo li takvu analizu bliskosti na usječnice u haikuima, dobivamo grub, ali i u odnosu na model objektivan pregled distance odnosno bliskosti između redaka, što može upućivati na tip pretapanja o kojem je riječ (bliske ili udaljene predodžbe). Ako se zbrajaju rezultati iz dva retka, onda numeričke vrijednosti mogu iznositi od 1 do 2 , što bi bio slučaj kad bi se u oba retka ponavljala samo ista riječ ili riječi. Najbliža je tome pjesma „Dim $\operatorname{dim} \operatorname{dim} \operatorname{dim} \operatorname{dim} / \operatorname{dim} \operatorname{dim} \operatorname{dim} \operatorname{dim}$ dim dim vi- / dim samo dim dim." (AHHP, 236; vrijednost 1,99), u kojoj se spojnica može učiniti kao usječnica (dolazi na kraju 12. sloga), ali se ustvari radi isključivo o interpunkcijskom znaku koji je upotrijebljen da bi se istaknula trodijelna struktura haikua. S iznimkom ovakvog ekstrema, prosjek vrijednosti bio je oko 1,35, a ovdje se navode pjesme iz obje zbirke sa spojnicama i uskličnicima 
(kao reprezentativnim usječnicama), prvo četiri s najnižom, a zatim četiri s najvišom numeričkom vrijednosti:

13. Gle, vjeverica! / Izdaleka je samo / kvrga na boru. (AHHP, 252; 1,17)

14. Na morskom žalu - / lagani val ispire / školjke u nizu. (NN 1, 192; 1,16)

15. Krila golubova - / to majka vješa rublje. / Igra se vjetar. (AHHP, 43; 1,01)

16. Gusjenica / pregrizla list - / prodiru zrake. (NN 1, 109; 1,04)

17. Gle, djetelina! / Sklopila je latice: / moli se Bogu. (AHHP, 84; 1,56)

18. Sjeverac pa jugo! / Vjetar pomeo vjetar / usred pustinje. (NN 2, 30; 1,67)

19. Lijepe jabuke / donijela unuku - / presretna baka! (AHHP, 81; 1,56)

20. pod prozorom / vrište mi mačke - / sanjam velikog psa (NN 1, 11; 1,60)

Objektivno, radi se o pjesmama čiji redci sadrže riječi koje se često pojavljuju zajedno u odnosu na riječi iz retka koji im slijedi nakon usječnice (13-16) i obrnuto, s riječima koje se javljaju u predvidljivom međuodnosu (17-20, npr. ,jugo”/,vjetar”, „unuku”/,baka”, „mačke”/,psa”).

Subjektivno, čini se da numerička vrijednost korelira s estetskom vrijednošću: pjesme iz prve polovice doimaju se podosta umjetnički uspjelije od pjesama iz druge polovice izbora. Glavni uzrok tome leži u kombinaciji banalnosti i blizine predodžbi koje se pojavljuju s obje strane usječnica u haikuima 17-20. U čitateljskoj recepciji zbog toga ne dolazi do „iskrenja” koje je preduvjet uspješnog haikua, a ta se razlika pogotovo vidi direktnom usporedbom pjesama 13 i 16, koje su formalno veoma slične. S druge strane, suprotna se opasnost previše udaljenih predodžbi ne realizira: pjesme iz prve polovice su uspješni haikui jer zahtijevaju određen kognitivni napor, ali opet ostaju u granicama klasično zacrtane poetike. Takva poetika, bez obzira na to koliko su određeni pjesnici s njome formalno upoznati, još uvijek ostaje glavni orijentir za tumačenje upućujući na vlastite pravilnosti koje, dakako, uključuju i upotrebu usjeka.

Za detaljniju i iscrpniju raspravu o realizacijama usjeka u hrvatskom antologijskom haikuu ovdje ponestaje mjesta, ali bitno je naglasiti da računalna analiza nudi mnoge još neistražene mogućnosti koje mogu proširiti znanje o usjeku i haikuu općenito. Pogotovo je obećavajuća maloprije naznačena mogućnost da se preko korelacije i eventualno intersubjektivne evaluacije 
pokuša identificirati određen indeks uspješnosti haikua - jesu li hrvatske pjesme s numeričkom vrijednosti korelacije riječi oko usjeka u iznosu 1,1 u pravilu uspješne, dok su one s vrijednošću oko 1,6 u pravilu neuspješne? Definitivan odgovor na to ovdje se ne može ponuditi, no može se još jednom ponoviti da hrvatski haiku poznaje usjek u velikom broju slučajeva i najčešće ga grafički realizira spojnicom i crticom kao odabranim usječnicama. Uz pjesme s usječnicama usred redaka i s usječnicama na kraju, kao i one bez usječnica, preko četiri petine antologijskih haikua sadrži usjek i prema tome one zadovoljavaju jedan od kriterija klasične poetike haikua.

Preostaje još samo naglasiti da, bez obzira na svu kompetenciju autora i strukturiranost teksta, aktualiziranje usjeka i omjeravanje njegove „snage” ovisi poglavito o čitatelju. Kako nas podsjeća Marshall raspravljajući o funkcionalnosti haikua, a koja se ostvaruje u procesu koji među ostalim uključuje pretapanje, radi se o procesu koji uključuje još jedan ključni element književnosti i ljudske spoznaje:

U svakom supostavljanju, svakom usjeku haikua, nalazi se procijep ... Doista, kako kaže Wolfgang Iser, upravo su procijepi mjesta na kojima čitatelji moraju doprinijeti značenjem kojima će književno djelo učiniti smislenim. ... 'Kad god se tijek [teksta] prekine', kaže Iser, 'i mi smo odvedeni u neočekivanom smjeru, daje nam se prilika da iskoristimo svoje sposobnosti uspostavljanja poveznica - ispunjavanja procijepa koje je ostavio sam tekst.' (Marshall 101)

Prema tome, usjek je u književnosti vrlo specifičan - budući da se kao takav pojavljuje samo u haikuima - ali istodobno i vrlo općenit, ne samo unutar svojega književnog roda, gdje se pojavljuje kao blizak cezuri, nego i u književnosti svake vrste gdje čitatelj svojim doprinosom omogućuje književnosti da živi. Metaforom iskre čitatelj zatvara književni krug od autora preko teksta i natrag, ali i električni krug koji nastaje kad ga haiku uspije zaokupiti i usjeći se u njezinu ili njegovu percepciju stvarnosti.

\section{Bibliografija}

Bagić, Krešimir. Rječnik stilskih figura. Školska knjiga, 2012.

Barnhill, David Landis. Bashō's Haiku: Selected Poems of Matsuo Bashō. State University of New York Press, 2004. 
Blasko, Dawn G. i Merski, Dennis W. „Haiku Poetry and Metaphorical Thought: An Invitation to Interdisciplinary Study." Creativity Research Journal, vol. 11, no. 1, 1998, pp. 39-46.

Blyth, Reginald Horace. A History of Haiku: In Two Volumes. Vol. 2. From Issa up to the present. Hokuseido, 1963.

Da, Nan Z. „The Computational Case against Computational Literary Studies.” Critical Inquiry, vol. 45, no. 3, 2019, pp. 601-39.

Devidé, Vladimir, ur. Antologija hrvatskoga haiku pjesništva. Naklada Pavičić, 1995.

Devidé, Vladimir, ur. Japanska haiku poezija i njen kulturnopovijesni okvir. Zagrebačka naklada, 2003.

Golumbia, David. „Death of a Discipline.” Differences, vol. 25, no. 1, 2014, pp. 156-76.

Guillory, John. „The Sokal Affair and the History of Criticism.” Critical Inquiry, vol. 28, no. 2, 2002, pp. $470-508$.

Hiraga, Masako. „'Blending' and an Interpretation of Haiku: A Cognitive Approach.” Poetics Today, vol. 20 , no. 3, 1999, pp. 461-81.

Kolar, Mario. „O muhama u krčmi ili može li haiku biti umjetničko djelo? Prilog proučavanju književnih mikrooblika." Književna smotra, vol. 42, no. 3/4, 2010, pp. 95-101.

Long, Hoyt i So, Richard Jean. „Literary Pattern Recognition: Modernism between Close Reading and Machine Learning." Critical Inquiry, vol. 42, no. 2, 2016, pp. 235-67.

Marshall, lan. „Stalking the Gaps: The Biopoetics of Haiku.” Mosaic: A Journal for the I nterdisciplinary Study of Literature, vol. 46, no. 4, 2013, pp. 91-107.

Moretti, Franco. „Conjectures on World Literature.” New Left Review, vol. 1, 2000.

Nikolić, Davor. „Digitalna humanistika i nacionalna filologija: o mogućim implikacijama računalnoga obrata." Croatica: časopis za hrvatski jezik, književnost i kulturu, vol. 40, no. 60, 2016, pp. 75-87. Parkes, Graham i Loughnane, Adam. „Japanese Aesthetics.” The Stanford Encyclopedia of Philosophy, 4.4.2018, www.plato.stanford.edu/archives/win2018/entries/japanese-aesthetics. Pristupljeno 6. lipnja 2020. 
Petrović, Svetozar. „Stih”. Uvod u književnost: Teorija, metodologija. Peto, poboljšano izdanje, ur. Zdenko Škreb i Ante Stamać, Nakladni zavod Globus, 1998.

Schmidt, Siegfried J. „Interpretation: The Story Does Have an Ending.” Poetics Today, vol. 21, no. 4, 2000, pp. 621-32.

Shirane, Haruo. „Beyond the Haiku Moment: Bashō, Buson, and Modern Haiku Myths.” Juxtapositions, vol. 1, no. 1, 2015, www.thehaikufoundation.org/juxta/juxta-1-1/. Pristupljeno 6. lipnja 2020.

Shirane, Haruo. Matsuo Bashō and The Poetics of Scent." Harvard Journal of Asiatic Studies, vol. 52, no. 1,1992 , pp. $77-110$.

Shirane, Haruo. Traces of Dreams: Landscape, Cultural Memory, and the Poetry of Bashō. Stanford University Press, 1998.

Škopljanac, Lovro. „Fantastična temporalnost u romanima Harukija Murakamija i Luke Bekavca”. Komparativna povijest hrvatske književnosti. Zbornik radova XVIII. Fantastika: problem zbilje, uredile Cvijeta Pavlović, Vinka Glunčić-Bužančić i Andrea Meyer-Fraatz, Književni krug Split Odsjek za komparativnu književnost Filozofskoga fakulteta Sveučilišta u Zagrebu, 2016.

Ueda, Makoto. Modern Japanese Poets and the Nature of Literature. Stanford University Press, 1983.

Višnjić Žižović, Sonja i Toyota Junichi. „Emptiness in Haiku Poetry.” Sense of Emptiness:

Interdisciplinary Approach, uredili Toyota Junichi, Pernilla Hallonsten i Marina Shchepetunina, Cambridge Scholars Publishing, 2012.

Vukelić Rožić, Đurđa, ur. Nepokošeno nebo: antologija hrvatskoga haiku pjesništva 1996-2007. Udruga tri rijeke, 2011.

Vukelić Rožić, Đurđa, ur. Nepokošeno nebo: antologija hrvatskoga haiku pjesništva 2008-2018. Udruga tri rijeke, 2018.

Wilson, Robert D. „An Interview with Hasegawa Kai.” Simply Haiku: A Quarterly Journal of Japanese Short Form Poetry, vol 3., no. 6, 2008, www.simplyhaiku.com/SHv6n3/features/Kai.html. Pristupljeno 6. lipnja 2020. 
Yasuda, Kenneth. Japanese Haiku: Its Essential Nature and History. Tuttle Publishing, 2011. 
[1] Autor harno zahvaljuje Đurđi Vukelić Rožić na ustupanju digitalnog primjerka antologije koju je uredila te dr. sc. Evi Cetinić s Instituta Ruđer Bošković na ustupanju digitalnog primjerka koda koji se odnosi na vektorski model; ovaj dio rada ne bi mogao nastati bez njihove pomoći.

\section{(c) (i) (2)}

Creative Commons Attribution-NonCommercial-NoDerivatives 4.0 International License 